\title{
Could Arctic ice be thinning?
}

\section{A. S. McLaren, R. G. Barry \& R. H. Bourke}

GloBAL warming in high latitudes, the predicted result of increasing greenhouse-gas emissions, could have important consequences for Arctic sea ice. Melting of the ice would lead to a decrease in both thickness and areal extent, and to more openings within the ice sheets. Most of the recent data on sea-ice thinning and opening have been provided by sonar measurements taken under the ice by submarines; they have not yet revealed any conclusive evidence of a trend towards widespread thinning. On page 795 of this issue ${ }^{\prime}$, Wadhams presents data collected north of Greenland by British submarines in October 1976 and May 1987, and shows that the mean sea-ice thickness is significantly less in the later year. The observation is provocative, but more data are required before one can hope to discern overall trends with any confidence.

The complex mixture of open water and ice of varying type and thickness that makes up the Arctic Ocean is a significant component of the global climate system. The geographical extent and thickness of the sea ice control the amounts of heat, moisture and momentum exchanged between the Arctic Ocean and the atmosphere. Climate models ${ }^{2}$ suggest that a doubling in levels of atmospheric $\mathrm{CO}_{2}$ should produce significant changes in the distribution of polar sea-ice extent and thickness. In turn, such changes would affect atmosphere-sea interactions and would have important implications for the climate of the Northern Hemisphere.

Since the late $1800 \mathrm{~s}$, when the earliest measurements of Arctic sea-ice thickness were taken, estimates of the overall mean thickness of pack ice have hovered around $3.0 \mathrm{~m}$. Nansen ${ }^{3}$ published the first measurements of Arctic basin sea-ice thicknesses collected during his voyage of 1893-1896 in the Fram. He reported an average thickness of floes in the region of the Transpolar Drift ranging from 3.1 to $3.8 \mathrm{~m}$. Field measurements ${ }^{+5}$ by groups in the Soviet Union indicated that old pack ice was not less than $3.0 \mathrm{~m}$ thick, that perennial ice ranged between 2.3 and $3.3 \mathrm{~m}$, and that the maximum thickness of non-ridged sea ice was between 3.0 and $5.0 \mathrm{~m}$. Thickness measurements taken during the 1968/69 British Trans-Arctic Expedition" gave an overall average of $4.2 \mathrm{~m}$; later papers ${ }^{7}$ provided revised estimates of $4.4-4.6 \mathrm{~m}$ and $3.7-3.9 \mathrm{~m}$ from the Pacific and Eurasian sides of the Arctic respectively, and a mean overall pack-ice thickness across the Arctic Basin of $3.7 \mathrm{~m}$ (ref. $8)$. But these field measurements, collected by drilling several hundred holes through the ice, provide an uncertain representation of the Arctic Ocean ice cover, which in places is heavily ridged and hummocked through wind-forced convergence and rafting of floes.

Since 1958, it has been possible to measure thicknesses using submarine sonar beneath the ice. The size of the 'footprint' sampled by the under-ice sonar depends on the instrument frequency/ beam-width ratio and the operating depth of the submarine. These observations are calibrated for the local sea level by measurements in areas of open water (leads and polynyas).

Based on US submarine cruise results for 1960 and 1962, Wittmann and Schule ${ }^{\text {II }}$ reported that the average Arctic pack-ice thickness was between 2.4 and $4.7 \mathrm{~m}$ with an overall average of $3.9 \mathrm{~m}$. Swithinbank $^{11}$, Williams et al. ${ }^{12}$, Wadhams ${ }^{1.3}$ and McLaren ${ }^{4.1+}$ reported sea-ice thickness distributions from four Arctic basin-wide submarine cruises, including those of the USS Nautilus (1958), USS Queenfish (1970), HMS Dreadnought (1971) and HMS Sovereign (1976). But none of these reports addressed the issue of trends in ice thickness. As each of the voyages travelled along different routes in different seasons and through various geographical areas, and in addition as there were differences in equipment and measurement accuracies, it was not possible to establish a reliable baseline against which to identify any trend.

There are few published data on the variability of Arctic ice thickness. Bourke and Garrett ${ }^{15}$ have presented seasonal climatologies of ice thickness in the Arctic Basin, deduced from unclassified submarine sonar data, but they made no reference to variability. McLaren ${ }^{14} \mathrm{com}$ pared ice thickness along the same basinwide transect during early August in two different years (1958 and 1970) by using submarine sonar data from different cruises. He found that ice was thinner across $941 \mathrm{~km}$ of the Canada Basin in 1970 (mean thickness of $2.39 \mathrm{~m}$ ) relative to 1958 (mean of $3.08 \mathrm{~m}$ ). Although the data from the two cruises varied considerably in overall quality, they were of similar quality across the Canada Basin, making this 0.69 -m difference significant.

Ice in the Canada Basin tends to circulate in a clockwise sense, but during the late summer this motion is reversed owing to the development of atmospheric cyclones $^{16.17}$. Such changes in ice motion lead to opening up of the ice, lowering concentrations by $20-30$ per cent ${ }^{1 /}$ relative to the previous season. If a reversal of this sort occurred in 1970 but not in 1958, the thinning observed by McLaren would be difficult to explain in terms of normal synoptic and interannual variability.
Unfortunately, the available atmosphericpressure data for those years lack the necessary accuracy to determine this.

Wadhams ' observation of thinning of the Arctic ice cover north of Greenland in 1987 relative to 1976 raises similar questions: is the Arctic ice really beginning to thin, or are there still insufficient available data to rule out normal synoptic and interannual variability? Recent studies ${ }^{\mathrm{t}}$ of sea-ice extent in the Arctic basin, based on satellite passive microwave data, have attempted to determine changes in ice cover that might indicate warming or cooling trends. Variations in global seaice extent remotely sensed by the Nimbus 7 satellite during 1978-1987 indicate no significant trends ${ }^{20}$; neither do data for 1973-1987 for sea-ice extent in the Northern Hemisphere ${ }^{21}$

The fact is that no data published so far can provide a reliable indication of whether the sea ice of the Arctic Basin is thinning, thickening or remaining essentially constant. Wadhams rightly stresses the importance of monitoring Arctic ice thickness on a systematic basis. A direct approach would involve statistical analysis by season, region and character of atmospheric circulation for each year of all the high-quality, comparable, basin-wide under-ice thickness distribution data obtained by US and British nuclear submarines since 1958. Only then might genuine trends be distinguished from natural variability.

A. S. McLaren and R. G. Barry are in the Cooperative Institute for Research in Environmental Sciences, University of Colorado, Boulder. Colorado 80309. USA. R. H. Bourke is in the Department of Oceanography, Naval Postgraduate School, Monterey, California 93943, USA

Wadhams, P. Nature 345, 795-797 (1990)

2. Manabe, S \& Stouffer, R. J Geophys, Res, 85,5529 5556 (1980)

3. Nansen, F. Geogr. J. 9. 473-528 (1897).

4. Zubov, N. N. Izdatel'stvo Glavsevmorputi (US Air Force Cambridge Research Center, 1943)

5. Zubov, N.N. Meteor. i. Gidro 2, 22-27 (1959).

6. Koerner. R. M. Weather 25, 215-228 (1970)

7. Koerner R. M. AIOJEX Bul 6. 11-26 (1971).

. Koerner. R. M. J. Glaciol. 12,173-185(1973).

.

9. McLaren, A. S. Arctic 41, 117-126 (1988)

. Wittmann, W. I. \& Schule, J. J. Proc. Symp. Arctic Heat Budget and Atmospheric Circulation 215-246 (Rand Corporation, Santa Monica, 1966)

11. Swithinbank, C. W. M. Proc. Int. Sea Conf. 246-254 (National Research Council of Iceland, 1971).

12. Williams, E., Swithinbank, C. W. M. \& Robin. G. de Q. J. Giaciol. 15, 349-361 (1975)

13. Wadhams, P. Phil. Trans, R. Soc Lond A302, 45-85 (1981).

14. MicLaren, A. S. J. geophys. Res. 94, 4971-4983 (1989).

15. Bourke, R. H. \& Garrett, R. P. Cold. Reg. Sci. Technol. 13 259-280 (1987)

16. McLaren, A. S., Serreze, M. C. \& Barry, R. G. Geophys. Res. Lett. 14, 1123-1126 (1987).

17. Serreze, M. C., Barry, R. G. \& MCLaren, A. S. J. geophys. Res. 94, 10955-10970 (1989).

18. Parkinson. C. L. et al. Arctic Sea Ice. 1973-1976: Satellite Passive Microwave Observations, NASA SP -459 (NASA, Washington, DC, 1987).

19. Barry, R. G. \& Maslanik, j. Geojour. 18.1, 35-44 (1989).

20. Gloersen, P. H. \& Campbell, W. J. J. geophys. Res. 93 10666-10674 (1988)

21. Parkinson, C. L. \& Cavalieri, D. J. J. Geophys. Res. 94. 14499-14523 (1989). 